\title{
Michał Gusin
}

\section{Logika sensu:}

Deleuze'a wprowadzenie do psychoanalizy

Gilles Deleuze znany jest jako filozof, który podjął głęboką debatę z psychoanalizą. Debata ta nie da się zredukować wyłącznie do krytyki, bowiem myślenie i pisanie Deleuze’a dokonuje się w przestrzeni niejednorodnej i wielowymiarowej. W Logice sensu freudowski projekt wzbogacony i przekształcony przez Melanie Klein czy Jacques'a Lacana służy do wskazania metafizycznej potencjalności psychoanalitycznych konceptów. Określając psychoanalizę jako „naukę o wydarzeniach”, Deleuze nie traktuje jej doktrynalnie, ale tworzy sieć powiązań pomiędzy rozmaitymi seriami psychoanalitycznych wglądów. W artykule próbuję pokazać, w jaki sposób Deleuze określa wprowadzenie do debaty z psychoanalizą. Kluczową koncepcją dla tego wprowadzenia jest termin „fantazmat”, który nawiązuje także do tradycji filozoficznej.

Słowa kluczowe: psychoanaliza, fantazmat, seria, wydarzenie 
Ciekawe, że to nie ja wyprowadzitem Feliksa z psychoanalizy, tylko on mnie.

Gilles Deleuze

W nocie do włoskiego wydania Logiki sensu z 1976 roku Deleuze pisze:

Co się nie udało w Logice sensu? Oczywiście, nosi ona jeszcze znamiona autentycznej życzliwości i poczucia winy wobec psychoanalizy. Moim jedynym wytłumaczeniem byłoby to, że próbowałem w sposób nieśmiały unieszkodliwić psychoanalizę, przedstawić ją jako sztukę powierzchni, która zajmuje się wydarzeniami jako jednostkami powierzchniowymi (Edyp nie jest niegodziwcem, ma tylko dobre intencje...).

Koncepty psychoanalityczne pozostały nietknęte, a Melanie Klein i Freud potraktowani z respektem. A teraz? Niestety, nie mogę mówić wyłącznie we własnym imieniu, ponieważ wszystko, co stało się od Logiki sensu, pozostaje zależne od mojego spotkania z Feliksem Guattarim, od mojej z nim pracy, tego, co robimy razem [...]. Anty-Edyp nie jest już ani wysokością, ani głębią, ani powierzchnią. Tu wszystko się wydarza, dzieje się - intensywności, wielości, wydarzenia - na pewnego rodzaju ciele sferycznym czy cylindrycznym obrazie: ciele bez organów ${ }^{1}$.

Słowa te, napisane po siedmiu latach od wydania Logique du sens, świadczą o przynajmniej trzech sprawach. Po pierwsze, psychoanaliza w tej książce ujmowana jest jako teoria pełna użytecznych pojęć, schematów i konceptów, które mogą być rozwijane na planie filozoficznym potwierdzają to liczne cytaty i odwołania do Freuda, Lacana, Klein, ale także Pontalisa czy Leclaire'a. Odwołania te mają charakter pokojowy - w tym sensie fundamenty koncepcji Freuda pozostały nietknięte w odróżnieniu od odwołań występujących w Anty-Edypie, które mają charakter subwersywny, a czasami wręcz wojenny, i prowadzą do zastąpienia psychoanalizy schizoanalizą. Po drugie, sojusz z psychoanalizą w wymiarze teoretycznym według rozważań z Logiki sensu jest nie tylko możliwy, ale i wskazany, stąd poczucie winy wobec psychoanalizy, której filozoficzna albo metafizyczna potencjalność ciągle nie została zaktualizowana. Można by pomyśleć, iż życzliwość Deleuze’a wobec psychoanalizy jest symetryczną figurą wobec „życzliwości” Lacana dla filozofii i podobnie zanika na początku lat siedemdziesiątych. Anty-Edyp stanowi jeden z kilku momentów w dwudziestowiecznej filozofii francuskiej, w których następuje odwrót od metafizycznej potencjalności

1 G. Deleuze, Note pour l'edition italienne de Logique du sens, [w:] tegoż, Deux regimes de fous, Paris 2003, s. 60. 
psychoanalizy, ale także, co zdaje się mniej rozpoznane, wpisuje się w drogę prowadzącą Lacana ku anty-filozofii. Po trzecie, aktywne działanie w polu teorii psychoanalitycznej polega na unieszkodliwieniu jej, przedstawieniu jako „sztuki powierzchni”. Oznacza to, że dokonująca się praca na poziomie pojęciowym, na poziomie potencjalności, zapoznaje groźny czy złowrogi charakter psychoanalizy, jej wymiar „polityczny” demaskowany w Anty-Edypie. Logika sensu, jak zobaczymy, przekształca psychoanalizę w teorię fantazmatów, a w pewnym sensie także w fantazmatyczną teorię, co później zostanie określone jako nieśmiała próba unieszkodliwienia, która się nie powiodła.

Komentarz napisany z perspektywy współpracy z Guattarim, w trakcie jej największej intensywności, wskazywać może na swego rodzaju rozczarowanie spowodowane zbytnią bliskością projektu Logiki sensu i psychoanalizy. W takiej też perspektywie można by powiedzieć, że jest to książka, która „zatrąca niemiło Freudem”2. Problem, jak się wydaje, leży jednak w tym, iż przynależąc do „etapu przejściowego” Deleuze'a, zawiera w sobie elementy nigdy później nierozwijane. A jednocześnie idealnie wpisuje się w serie jego wcześniejszych książek. W wielu bowiem aspektach stanowi dopełnienie bądź uzupełnienie Różnicy i powtórzenia. W znaczeniu uzupełnienia stanowi próbę realizacji książki filozoficznej, która nawiązuje do technik pokrewnych „na przykład teatrowi czy filmowi” - zamiast rozdziałów mamy wzajemnie implikujące się serie, w całościowym horyzoncie książki eksplikujące, ażeby w recepcji czytelniczej wyrazić complicatio ${ }^{3}$. Historia filozofii, będąc medium, w którym komunikacja między seriami znajduje wyraz, opowiada się na nowo. Tak jak w książkach poświęconych Nietzschemu, Kantowi czy Spinozie. Ale też inaczej - sobowtór jest w pełni uprzedni w stosunku do myśliciela, nie jest jego pasożytem, ale duchem odkupicielem z chaosu, życiem podwojonym, a na mocy complicatio „unieskończonionym”. Uzupełnienie oznacza więc zapewnienie ciągłości tworzącego się dzieła: uznany historyk filozofii publikuje książkę par

2 W anglojęzycznym wydaniu słowa z przedmowy "ce live est un essai de roman logique et psychanalytique" zostały przetłumaczone jako "This book is an attempt to develop a logical and psychological novel". Pomyłka ta stanowi swego rodzaju świadectwo recepcji Deleuze’a jako zagorzałego wroga psychoanalizy.

3 „Trójca komplikacja-eksplikacja-implikacja zdaje sprawę z całego systemu, to znaczy z chaosu, który wszystko zawiera, z dywergentnych serii, które się zeń wyłaniają i doń powracają [...]. Każda seria eksplikuje się lub rozwija tylko w swojej różnicy z innymi seriami, jakie implikuje i jakie ją implikują, jakie zwija i jakie ją zwijają - w tym chaosie, który wszystko komplikuje.” - G. Deleuze, Różnica i powtórzenie, tłum. B. Banasiak, K. Matuszewski, Warszawa 1998, s. 185.
Logika sensu, jak zobaczymy, przekształca psychoanalizę w teorię fantazmatów,

a w pewnym sensie także w fantazmatyczną teorię, co później zostanie określone jako nieśmiała próba unieszkodliwienia, która się nie powiodła 
excellence filozoficzną, którą jest Różnica i powtórzenie, aby uzupełnić przejście od historii filozofii do filozofii samej tym, co zwie się logiką sensu. Nazwa jest samym przedmiotem: logika określa (minimalny) zespół reguł i prawideł, na mocy których myśli i wypowiedzi są komunikowalne, tworzą więc sens wspólny; logika sensu to sensu powtórzenie, w którym na nowo skonfrontowani jesteśmy z sytuacją poprzedzającą narodziny myśli.

Ale Logika sensu jest też dopełnieniem Różnicy i powtórzenia, tak jak dopełnieniem zbioru jest wszystko, co do niego nie należy. Powtarzające się motywy obu książek realizują inne kierunki, stanowią przykład syntezy dysjunktywnej. Motyw psychoanalizy, bądź co bądź odgrywający fundamentalną rolę w książce bezpośrednio następującj po Logice sensu, stanowi przykład afiliacji filozoficznej. I Różnica..., i Logika... są zauważone przez Lacana, który w seminarium XVI, zachęcając swoich słuchaczy do lektury obydwu prac, odnotował:

przez sam swój tytuł Różnica i powtórzenie wykazuje powiązania z moim dyskursem, o czym jej autor z pewnością dobrze wie. Dlatego też byłem mile zaskczony, znajdując na półce książkę, która daje nam jeszcze więcej - zaskoczony tym bardziej, że kiedy ostatnio go widziałem, nic mi o niej nie wspominał i nazywa się Logika sensu. [...] warto zauważyć, że miał szczęście, mogąc poświęcić czas na wyartykułowanie i zgromadzenie w jednym tekście nie tylko tego, co w istocie głosił mój dyskurs - a nie ma wątpliwości, że dyskurs ten jest w centrum jego książek, skoro przyznaje, że Seminarium o Skradzionym o liście tworzy pewnego rodzaju warunek wstępny, definiuje próg - ale także [na wyartykułowanie] tego, co według mnie wzbogaca mój dyskurs ${ }^{4}$.

Ta uwaga pochodząca od samego mistrza dobrze pokazuje kierunek, w którym Deleuze zmierzał pod koniec lat sześćdziesiątych. Logika sensu w znaczeniu dopełnienia będzie także (a może przede wszystkim) wprowadzeniem do psychoanalizy. Przy czym wprowadzenie ma tu charakter wieloznaczny. $Z$ jednej strony daje około-strukturalistyczną wykładnię psychoanalizy, czyli powtarza w teoretycznie skondensowanej formie drogę Lacana z połowy lat pięćdziesiątych, z drugiej redefiniuje strukturalizm przez odwołania do psychoanalizy, i to redefiniuje w sposób krytyczny. Tak jak Heidegger postulował wprowadzenie do metafizyki jako jej ponowne przemyślenie (w medium historii filozofii), tak Deleuze proponuje powtórzenie strukturalistycznego momentu psychoanalizy („Ta książka jest próbą powieści logicznej i psychoana-

4 J. Lacan, Le Séminaire, Livre XVI: D'un autre à l'autre (1968-69), Paris 2006, s. 218. 
litycznej zarazem." ${ }^{5}$ ). Ten moment strukturalistyczny nie jest jednak tożsamy ze źródłowym Lacanowskim „powrotem do Freuda”. Idzie tu raczej o swoistą potencjalność zawartą w procesie fantazmatu albo wydarzenia. Sama psychoanaliza ma być „nauką o wydarzeniu”, i to właśnie wokół niego konstytuować się będzie Deleuzjański gest wobec dziedzictwa Freuda.

Deleuze jest jednocześnie profanem, doskonale psychoanalizie obcym, niewiernym, który niemniej pozostaje jej przychylny. Jak powie już po publikacji Anty-Edypa: ,nie byłem obciążony ani odpowiedzialnością psychoanalityka, ani poczuciem winy i różnymi innymi uwarunkowaniami związanymi ze statusem pacjenta" ", co pozwalało mu na pracę pojęciową „w dodatku w fazie zalążkowej”. I na tym etapie jest Logika... - opracowuje psychoanalityczne koncepty (Edyp, kastracja, ciało jako mnogość stref erogennych itd.), które przeplatają się w koncepcji wydarzenia. Teoretyczny projekt psychoanalizy rozumiany jest jako opracowywanie genezy znaczeń, które konstytuują się wokół różnych zdarzeń w życiu podmiotu, w szczególności zdarzeń traumatycznych podlegających procesowi wyparcia. W takim też najogólniejszym znaczeniu Deleuze pisze, iż psychoanaliza ,jest nauką o wydarzeniach, pod warunkiem, że nie traktujemy wydarzenia jako czegoś, czego sens należy odnaleźć i wydobyć" (282). Wydarzenie jest pojawieniem się sensu będącego granicą, powierzchnią rozdzielającą, dystansem między zdaniem a stanem rzeczy, do którego się ono odnosi - wydarzenie jest sensem samym „pod warunkiem, że nie myli się wydarzenia z jego czaso-przestrzenną realizacją" (43). Wiąże się to z kolejną charakterystyką: jako nauka psychoanaliza odtworzyć ma logikę czy też porządek, w jakim rzeczywiste zdarzenia podmiotu stają się dla niego zdarzeniami znaczącymi: „Praca analizy [...] polega na umożliwieniu dotarcia do tego nieświadomego porządku reprezentacji 'wypartych', ażeby odtworzyć jego logikę, odkryć za każdym razem jego osobliwą/jednostkową [singulier] spoistość”. Deleuze'a jako filozofa interesuje oczywiście nie praktyka (klinika), ale możliwość określenia samego aktu myślenia, czasownika „myśleć”, będącego osobliwością, wokół której konstytuuje się Ja (zob. 160), za pomocą teorii psychoanalitycznej.

5 G. Deleuze, Logika sensu, tłum. G. Wilczyński, Warszawa 2011, s. 14. Dalej cytaty z tego wydania lokalizuję, podając numer strony w nawiasie.

6 G. Deleuze, Negocjacje: 1972-1990, tłum. M. Herer, Wrocław 2005, s. 26.

7 S. Leclaire, Psychanalyser, Paris 1968, s. 58. 


\section{Fantazmat psychoanalizy}

W ukonstytuowanej wersji psychoanalizy oddziaływanie słowa na ciało, tego, co językowe, na to, co somatyczne, przyjmie postać dualnej artykulacji popędu: afektu i przedstawienia/wyobrażenia [Vorstellung]. Dualność tę wyjaśnić można względnie łatwo, jako kumulację i/lub rozładowanie napięcia na poziomie cielesnym (odczucie przykrości i/lub rozkoszy) oraz towarzyszące temu wspomnienie bądź wyobrażenie. Wyobrażenie może reprezentować się na płaszczyźnie somatycznej, czego najlepszym przykładem były objawy histeryczne, w których ciało zachowuje się wbrew nauce anatomii; i odwrotnie - pobudzenie cielesne (przyjemność/przykrość) może reprezentować się czy też „wyczerpywać” w wyobrażeniu. Freud wokół tej dualności sklasyfikuje cechy dystynktywne nerwicy, psychozy i obsesji (fobii). Psychoanaliza nigdy nie mogła wyrzec się owej dwoistości, a mówiąc jeszcze inaczej: psychoanaliza zredukowana wyłącznie do praktyki dyskursywnej, wyłącznie do mówienia, nie jest psychoanalizą - język, mowa i mówienie występują w ścisłym związku $\mathrm{z}$ afektywnym stanem wypowiadającego podmiotu. Psychoanaliza jako nauka, nawet jeśli jest to tylko nauka w stanie powstawania, quasi-nauka czy też projekt nauki o nieświadomości, będzie miała na celu wyjaśnienie tej podwójnej artykulacji mówiącego ciała. W tym znaczeniu wszelkie teoretyczne toposy psychoanalizy zostają wypracowane na gruncie materiału terapeutycznego. Podmiot znaczącego, czyli podmiot wypowiadający (mówiący) występuje w szczególnym związku z podmiotem jouissance, czyli podmiotem doznającym (przyjemności/bólu). Ten pierwszy odpowiada Freudowskiej artykulacji na poziomie wyobrażenia/przedstawienia, ten drugi - afektu. Dla Deleuze'a, któremu chodzi nie tyle o podmiotowość i subiektywność, ile o procesy je wytwarzające, ważne będą te konstrukcje psychoanalizy, które niczym rozważania stoików o ciałach i efektach, pokazują wzajemne oddziaływanie czy przenikanie się owych stref pękniętego podmiotu. Odwoływał się więc będzie zarówno do Lacana, jak i Melanie Klein. Na poziomie konceptualnym fantazmat będzie stanowić konstrukcję najbliższą wydarzeniu (seria 30, 282-285).

W Stowniku psychoanalizy Laplanche'a i Pontalisa, do którego Logika... wielokrotnie się odwołuje, fantazmat w najogólniejszym znaczeniu określany jest jako wyobrażony scenariusz, w którym „podmiot, w sposób mniej lub bardziej zniekształcony przez procesy obronne przedstawia spełnienie jakiegoś pragnienia" ${ }^{8}$. Psychoanaliza odkrywa leżącą u podłoża

8 J. Laplanche, J.B. Pontalis, Stownik psychoanalizy, tłum. E. Modzelewska, E. Wojciechowska, Warszawa 1996, s. 52. 
wszelkich fantazmatów formę uniwersalną w postaci fantazmatu pierwotnego. Najlepszym i zarazem najbardziej adekwatnym przykładem dla Deleuzjańskiego wprowadzenia może być analiza Człowieka-Wilka i Człowieka-Szczura wraz z późniejszymi komentarzami. Odniesienia do nich pojawiają się w Logice sensu kilkakrotnie, ilustrując samą koncepcję fantazmatu oraz metodę serialną. Jeśli chodzi o analizę Człowieka-Szczura ${ }^{9}$, szczególnie interesujący jest dla Deleuze'a komentarz Lacana. Powołuje się na niego w serii szóstej, popełniając przy tym zabawną czynność pomyłkową: „Weźmy jego [Lacana] komentarz do człowieka od wilków, wykazujący istnienie serii w nieświadomości [...] i wskazujący na szczególną rolę, jaką w obu seriach odgrywa element »długu «" (67). Człowiek-Wilk (albo „człowiek od wilków”, jak funkcjonuje to w języku francuskim) zastąpił Człowieka-Szczura.

W Lacanowskim opracowaniu ważne jest także to, co zostanie przetworzone w koncepcję fantazmatu:

w sercu doświadczenia analitycznego istnieje coś, co powinno właściwie nazywać się mitem, mitem jako dokładnie tym, co może być zdefiniowane jako nadające formułę dyskursywną temu, co nie może być przekazane w definicji prawdy [...]. Mówienie nie może uchwycić tego momentu dostępu do prawdy jako prawdy obiektywnej, może go wyrazić tylko w sposób mityczny ${ }^{10}$.

Psychoanaliza jako teoria oparta na praktyce, sztuka w średniowiecznym znaczeniu sztuk wyzwolonych [arts libéraux] udostępnia coś, co nie daje się zobiektywizować w postaci formuł nauki i wyraża się w postaci mitycznej. Lacan nazwie to „indywidualnym mitem nerwicy” jako swoistą inscenizacją, mitycznym pejzażem, w którym podmiot rekonstruuje własną historię. I nie jest to historia obiektywna, ale za to sensowna, pełna różnego rodzaju elementów odgrywających szczególną rolę w życiu podmiotu. W psychoanalizie jako technice chodzi o ich wyodrębnienie, wyodrębnienie ich układów, serii rozumianej jako szereg elementów wzajemnie do siebie odsyłających za sprawą czegoś, co jest w stosunku do nich całkowicie heterogeniczne. W wypadku Człowieka-Szczura była to seria zapoczątkowana opowieścią o chińskiej torturze, opowieścią, która stanowiła katalizator dla czynności natrętnych, z powodu których Ernest Lanzer zgłosił się do Freuda, a jednocześnie punkt zbieżności, wokół którego organizować się będzie relacja do zmarłego ojca i ukochanej kobiety. Analiza tego przypadku polega na uporządkowaniu

9 Z. Freud, Uwagi na temat pewnego przypadku nerwicy natręctw, [w:] tegoż, Charakter a erotyka, tłum. R. Reszke, D. Rogalski, Warszawa 1996, s. 23-83.

10 J. Lacan, Le mythe individuel du névrosé, Paris 1956, s. 322. 
występujących tu ciągów znaczeniowych, serii wzajemnie się wywołujących i rezonujących (seria synowska i seria ojcowska).

W Lacanowskiej analizie człowieka od szczurów występuje na przykład seria ojca, która bardzo wcześnie pobudza dziecko i należy do historii rodzinnej (dług - przyjaciel - kobieta bogata - kobieta biedna), a także seria o tych samych elementach, ale zamaskowanych i przesuniętych, którą podmiot sam odnajduje później już na własną rękę (gdzie dług gra rolę przedmiotu = x, który wprawia $\mathrm{w}$ rezonans obie serie) (303).

Analizowany i opisany przez Freuda przypadek Siergieja Pankiejewa stanowi wzorcowy przykład tego, w jaki sposób zdarzenie z historii podmiotu staje się wydarzeniem w znaczeniu Deleuze'a. Co więcej, dekadę później, w drugim tomie Kapitalizmu i schizofrenii, napisanym wspólnie z Guattarim, znajduje się ostatni tekst poświęcony wprost psychoanalizie, który jest swego rodzaju trawestacją psychoanalitycznych rozważań nad historią Człowieka-Wilka.

Dla Freuda analiza zaprezentowana w $Z$ historii nerwicy dziecięcej stanowiła ważną aplikację już opracowanej teorii i mocny dowód skuteczności metody interpretacji psychoanalitycznej. Pacjent nazwany Człowiekiem-Wilkiem, po wielu bezowocnych próbach leczenia u ówczesnych lekarzy, zwrócił się do twórcy psychoanalizy w nadziei na pomoc. Freud odnalazł źródło jego aktualnych zaburzeń w historii dzieciństwa. Stosując metody opracowane w Objaśnianiu marzeń sennych i biorąc poprawkę na zniekształcenia pamięci obejmującej wspomnienia i przeżycia z dzieciństwa analizanta, zrekonstruował źródłowe doświadczenie, które naznaczyło w sposób retroaktywny rzeczywistość psychiczną Człowieka-Wilka. Kluczowe jest marzenie senne, za sprawą którego Pankiejew nabył psychoanalityczny kryptonim Człowieka-Wilka. Jego treścią jawną jest obraz wilków siedzących na drzewie i intensywnie wpatrujących się w śniącego. Analityczna interpretacja tego snu doprowadziła do odkrycia „sceny pierwotnej”, którą w tym wypadku był akt seksualny rodziców a tergo - Człowiek-Wilk jako półtoraroczne dziecko był świadkiem tej sceny uzyskującej znaczenie za sprawą mechanizmu naznaczenia wstecznego. Naturalne wydaje się pytanie o ontologiczny status owego zdarzenia: czy rzeczywiście miało miejsce, czy też jest konstrukcją analityczną oraz pewnym scenariuszem, w którym jak w soczewce skupia się charakter psychoanalitycznego projektu teoretycznego. W Logice sensu, w której chodzi o pokazanie genezy wydarzenia jako bytu metafizycznego, transcendentalnego i topologicznego jednocześnie, Freudowska analiza odgrywa rolę przykładu wyjściowego. Gdy Deleuze charakteryzuje fantazmat jako to, co nie reprezentuje ani działania, ani 
doznania, ale „wynik działania i doznania”, równocześnie uchyla rozróżnienie pomiędzy wyobrażonym a rzeczywistym stanem rzeczy jako substancją wydarzenia. Freud także zmniejszył wagę tego rozróżnienia („sam chciałbym wiedzieć, czy scena pierwotna była fantaz)ą, czy realnym przeżyciem mego pacjenta, ale biorąc pod uwagę inne podobne przypadki, należy stwierdzić, że rozstrzygnięcie tej kwestii nie jest właściwie aż tak bardzo ważne"11) - i właśnie to sprawia, że psychoanaliza rozpoznaje proces tworzenia się fantazmatów jako zakorzenionych w rzeczywistej historii podmiotu, ale na nowo ową historię przetwarzających (naznaczenie wsteczne) czy zakrzywiających. Stanowią przeto coś w rodzaju powierzchni, na której zostają zarejestrowane zdarzenia: powierzchni łączącej i rozdzielającej ową wewnętrzność podmiotu, jego mityczno-metafizyczną subiektywność i stronę zewnętrzną, czyli asymetrycznie mityczno-fizyczną obiektywność. I ze względu na ten „dwustronny” charakter w fantazmacie dokonuje się przejście od przeżycia psychicznego (pseudo-przyczyna, zdarzenie wyjściowe) do struktury logicznej (efekt, artykulacja językowa, interpretacja analityczna) i odwrotnie: następuje ustrukturowanie wrażeń poprzez ich „rejestrację” na powierzchni. W terminologii Freudowskiej proces ten nazywa się naznaczeniem wstecznym. Podlega mu nie tyle całe traumatyczne przeżycie, ale te jego elementy, które nie mogły zostać w pełni wprowadzone do kontekstu znaczeniowego przeżywającego podmiotu (obserwacja aktu seksualnego rodziców). Wraz z pojawieniem się zdarzeń umożliwiających stworzenie kontekstu dla tych nieogarniętych elementów następuje retroaktywne opracowanie całości traumatycznego zdarzenia. Uprzywilejowanym polem tego procesu jest seksualność, ze względu na charakterystyczną dla niej zmienność w czasie. Innymi słowy: w fantazmacie jako „rejestracji wydarzenia” dokonuje się dysjunktywna synteza - przeszłe zdarzenie rozwidla się na ciągi znaczeniowe, które aktywizują się w zależności od siły pobudzenia (interpretacja analityczna jako pobudzenie) występującej w teraźniejszości. Późniejszy zarzut wobec psychoanalizy polegał będzie m.in. na tym, że jej model teoretyczny oparty jest na redukowaniu owych ciągów, na blokowaniu siły „produkcyjnej nieświadomości” realizującej się w fantazmacie sprowadzonym stale do tego samego (Edyp, ojciec, kastracja).

Pisząc Logikę sensu, Deleuze korzysta z tropów psychoanalitycznych celem zużytkowania ich we własnej koncepcji metafizycznej. Użytek taki jest możliwy, gdyż Deleuze postrzega psychoanalityczne konstrukcje jako metafizyczne potencjalności. Analityczne pojęcie fantazmatu

11 Z. Freud, Dwie nerwice dziecięce, tłum. R. Reszke, Warszawa 1996, s. 175.
Pisząc Logikę sensu, Deleuze korzysta

z tropów

psychoanalitycznych celem zużytkowania ich we własnej koncepcji metafizycznej. Użytek taki jest możliwy, gdyż Deleuze postrzega psychoanalityczne konstrukcje jako metafizyczne potencjalności 
posłużyć może zilustrowaniu serializmu, tego, co nazwane zostało porządkowaniem w serie [mise en serie], jako pewnej metafizyki strukturalizmu. W serii piątej zostaje określony paradoks polegający na regresji w nieskończoność, występujący w samym akcie nazywania: ażeby zdefiniować daną nazwę, potrzebuję nazwy, która wymaga definicji, i tak ad infinium. Zważywszy na wagę rozróżnienia podstawowego (seria 3, 30-39) czterech wymiarów zdania jako elementu systemu językowego (wskazywanie, manifestowanie, znaczenie i sens) można powiedzieć, że sens wypowiedzi stając się przedmiotem wypowiedzi kolejnej, multiplikuje się bez końca. Sytuacja ta znana jest zarówno w logice, gdzie próbowali ją zażegnać Russell czy w inny sposób Wittgenstein, jak i w życiu codziennym, co w odwróconej wersji ilustruje Lewis Carroll, opisując spotkanie Alicji z Białym Rycerzem, który zapowiada tytuł piosenki (53). Deleuze rozważa seryjną postać owego regresu w serii szóstej pod kątem tego, jak powoduje on podwojenie albo rozdwojenie samej serii typu n1, n2, n3, n4.... „forma seryjna z konieczności powstaje wszędzie tam, gdzie pojawiają się co najmniej dwie równoczesne serie” (62). Występuje tu seria terminów definiujących i terminów zdefiniowanych, przebiegająca nazwy: n4 desygnuje n3, które desygnuje n2, które desygnuje n1, oraz n1 desygnowane przez n2, które desygnowane jest przez n3, które desygnowane jest przez n4. Wydawać by się mogło, że obie serie są wymienne, ze względu jednak na to, że w pierwszej serii każdy termin desygnuje sens następnego, a w drugiej jest desygnowany przez kolejny, mamy do czynienia z relacją, która nie jest symetryczna: A jest w relacji z B wtedy, gdy B oznacza sens A, co nie jest równoważne temu, że A oznacza sens B, czyli że B jest w relacji z A. Jak zauważa James Williams we wprowadzeniu do Logiki sensu:

U Deleuze'a relacje nie są symetryczne ani przechodnie. W momencie, gdy przechodzimy do drugiego elementu relacji, pierwszy zostaje przez owo przejście zmieniony. Gdy mówię, że 'warczenie' znaczy 'złość', to 'złość' desygnuje znaczenie 'warczenia', ale gdy powiem, że 'złość znaczy 'wściekłość', wówczas 'wściekłość' desygnuje znaczenie 'złości', która nie jest już tym, co desygnuje znaczenie 'warczenia', ale specyficznym znaczeniem desygnowanym przez 'wściekłość' ${ }^{2}$.

Powoduje to, że nie tylko znaczenie i sens stanowią niedające się ograniczyć pole do definiowania (i interpretowania), ale także samo definiowanie i oznaczanie rozkładają się w serie: „Ład serii jest więc w istocie wieloseryjny” (63). Regres jako źródło wszelkich paradoksów albo „arcy-

12 J. Williams, Gilles Deleuze's Logic of Sense: a Critical Introduction and Guide, Edinburgh 2009, s. 185. 
paradoks" (62) nie polega wyłącznie na ucieczce w nieskończoność tropionego sensu (interpretacja psychoanalityczna sceny pierwotnej), ale przede wszystkim na tym, że elementy serii wytwarzają nową serię, której prawo funkcjonowania jest nieredukowalne do prawa pierwszej serii:

W istocie owe dwie heterogeniczne serie mogą być określane na rozmaite sposoby. Może być to seria wydarzeń i seria rzeczy, w których wydarzenia te się urzeczywistniają bądź też nie, seria złożona z desygnujących zdań bądź i seria desygnowanych przez nie rzeczy [...]. Rozróżnienia te są bez znaczenia [...]. Ważniejsze jest to, że można konstruować obie serie w postaci na pozór jednorodnej (63).

Ilustruje to psychoanaliza jako teoria fantazmatów.

Fantazmat w odróżnieniu od takich obiektów psychoanalizy, jak marzenia senne, czynności pomyłkowe czy symptomy chorobowe, które powstają niezależnie od woli podmiotu, wyłaniając się niejako z głębi i stanowiąc przedmiot myślenia, jest współtworzony przez podmiot, wyprowadza albo przekształca wewnętrzność, niedostępną głębię w zewnętrzne otoczenie i jest już myśleniem (a nie tym, co do pomyślenia i w efekcie do zinterpretowania). Jak pisze Deleuze, fantazmat jest wyjątkowo ruchliwy, a więc „swobodnie przemierza dystans dzielący różne systemy psychiczne”, a także przemieszcza się w swoim rozwoju diachronicznym: może na nowo opracować własny początek, „wchłonąć w siebie własne źródło" (290). W takim znaczeniu stanowi środowisko [milieu] dla rozwarstwiającej się serii, to, co zapewnia jej szczególną jednorodność. Ujmując rzecz jeszcze inaczej, jeśli w wypadku marzenia sennego rozwarstwienie serii polega literalnie na odchyleniu pomiędzy samym przeżyciem snu (stan rzeczy) a jego artykulacją językową, pozostaje ona w tym znaczeniu niejednorodna - u Lacana będzie to problem realnego w stosunku do symbolicznego, ale też kwestia wspomnianej różnicy pomiędzy podmiotem afektu a podmiotem przedstawienia spojenie zaś, tylko asymptotyczne (jako proces nieskończony), dokonuje się w procesie interpretacji zapewniającym pozorną jednorodność (marzenie senne jako spełnienie pragnienia, którego poszukuje interpretacja). Proces interpretacji zaś polega na ustalaniu korespondencji w serii artykulacji językowej rozwarstwiającej się pomiędzy treść jawną marzenia sennego a treść ukrytą, między serią znaczących a serią znaczonych. Tym, co stanowi warunek możliwości ich korespondencji, jest paradoksalna instancja pustej przegródki, to, czego brakuje na jego miejscu, czemu brakuje własnej tożsamości, brakuje podobieństwa do siebie samego i własnego źródła pochodzenia (68). W słowniku psychoanalitycznym jest to fallus („Nie musimy tu przypominać charakterystycznych właściwości fallusa, wyodrębnionych przez Lacana w jego słynnych pracach” 
- 303), znaczące pragnienia, ale także to, co pozwala wyobrażać sobie jakąkolwiek reprezentację, jakiekolwiek przedstawienie. Mamy więc serię zbieżną, której granica jest ewokowana w interpretacji (przykład interpretacji dużej części marzeń sennych w Objaśnianiu marzeń sennych), mamy serię, która rozwarstwia się na co najmniej dwie serie albo zbiegające do tej samej granicy, albo do różnych granic, albo wreszcie rozbieżne. „Fantazmat, przynajmniej w chwili swych narodzin, nie jest niczym innym, jak tylko wewnętrznym rezonansem między dwiema

Jak więc mamy

rozumieć

sformułowanie, że „psychoanaliza

w ogóle jest nauką

o wydarzeniach"?

$\mathrm{O}$ jakim rodzaju nauki jest tutaj mowa? $\mathrm{Na}$ odpowiedź składają się trzy elementy niezależnymi seriami seksualnymi, o ile rezonans ten przygotowuje nadejście wydarzenia i zapowiada jego ujęcie” (304). Mowa tu o seriach seksualnych (oralnej, pregenitalnej i edypalnej), ponieważ wraz z seksualnością, czyli wyodrębnieniem się popędów seksualnych z całej masy sił (aktywnych i reaktywnych), w oddziaływanie których podmiot jest uwikłany, „zaczyna się seria, albowiem forma seryjna jest formą organizacji powierzchni” (298). W jakim sensie rezonans między seriami przygotowuje nadejście wydarzenia? Przykładem może być seria obrazów, wspomnień, słów, znaków, symptomów czy czegokolwiek innego, wchodząca w komunikację z inną serią i wywołująca doznanie cielesne. Ich wzajemne oddziaływanie staje się początkiem wyobrażonego scenariusza, o ile owo doznanie niezależnie od intensywności będzie czymś, co podmiot będzie starał się odtworzyć, co będzie jego jednostkowym albo osobliwym wydarzeniem. To oddziaływanie, ten rezonans jest niczym innym, jak tylko momentem, w którym podmiot doświadcza sensu jako przebłysku, jako tego, co jest poza-bytem i trwaniem jednocześnie, jest „owym minimum bytu, które odpowiada wszystkiemu, co trwa. W tym właśnie znaczeniu stanowi "wydarzenie«" (43). Nie chodzi tu tylko o konotacje seksualne - doznaniem cielesnym jest również myśl, myślenie jako takie: powierzchnia fizyczna i powierzchnia metafizyczna w fantazmacie właśnie dlatego w siebie przechodzą (zob. 278): „Wzór fantazmatu jest następujący: od seksualnej pary do myśli, za pośrednictwem kastracji”. Fantazmat jest myśleniem samym, zapowiadającym wydarzenie-sens i tworzącym przestrzeń (teatralną scenę) dla jego ujęcia: psychoanalityczny podmiot znaczącego i podmiot jouissance krzyżują się.

Jak więc mamy rozumieć sformułowanie, że „psychoanaliza w ogóle jest nauką o wydarzeniach”? O jakim rodzaju nauki jest tutaj mowa? $\mathrm{Na}$ odpowiedź składają się trzy elementy. Po pierwsze, nie będąc psychoanalitykiem, Deleuze nie przejmował się „wiernością” doktrynie - na kartach Logiki sensu swobodnie kontaminował terminy pochodzące od Lacana i od Klein - ani, co z tym związane, z jej wymiarem praktycznym. Psychoanaliza to w jego ujęciu pewien zestaw narzędzi, które można stosować w projekcie logiki sensu, czyli przy określaniu problemu genezy 
myślenia w szerokim sensie; można za ich pośrednictwem ilustrować działanie metody serialnej i jej odpowiedniość dla logiki sensu. Na takim poziomie byłoby to postawienie „metodologicznego problemu” koncepcji. Dlatego też Lacan mógł odnaleźć swój dyskurs w narracji Deleuze’a. Dodajmy, że dyskurs miniony - czyli usłyszeć własne echo. W kontekście historycznym warto zauważyć, że druga połowa lat sześćdziesiątych to przejście Lacana od „pierwszego klasycyzmu” do drugiego, a więc postawienie na nowo kwestii „naukowości” psychoanalizy ${ }^{13}$.

Po drugie, „nauka o wydarzeniach” to wynalazek stoików, którzy przeformułowali platońską episteme albo nawet dokonali „odwrócenia platonizmu", co w obrazowy sposób opisane zostało w serii osiemnastej. Platoński problem, który dotyczył będzie także rozumienia fundamentalnego pojęcia psychoanalizy, polega na określeniu zasięgu Idei: czym jest to, co w Idei nie uczestniczy, co nie jest przez nią reprezentowane - to pytanie o symulakrum. W tradycji filozoficznej jest to problem pozoru, złudzenia, nonsensu, ale też, ujmując rzecz w kategoriach przestrzennych, problem rozróżnienia wnętrza i zewnętrza, głębi i wysokości. Stoicy są w odczytaniu Deleuze’a tymi, którzy „ujawniają” mroczną głębię i oślepiającą wysokość. Ich nauka dotyczy tego, co

wymknęło się Idei, wypływa na powierzchnię, zdąża do bezcielesnej granicy, by odtąd reprezentować wszelką możliwą idealność, pozbawioną jednak właściwej jej przyczynowej i duchowej skuteczności [...]. Symulakry tracą odtąd swój status podziemnych buntowników, za to uwydatniać się będą ich 'efekty' (nie dbając o terminologię stoicką, można by je nazwać 'fantazmatami'). To, co najgłębiej skryte, stało się czymś najbardziej jawnym (24).

Jeśli odnieść to teraz do psychoanalizy jako teorii nieświadomego, pojawia się następujący schemat. Koncepcja Freuda traktuje o nieświadomości jako części aparatu psychicznego, jako czymś, co nie da się zredukować do przejrzystej instancji świadomości, co może być oddane za pomocą metafory mrocznej głębi albo też góry lodowej, która zanurzona jest pod powierzchnią. Bazując na tej metaforze, psychoanalizę odczytywać można na trzy sposoby: jako koncepcję psychologiczno-biologiczną, kulturowo-hermeneutyczną i wreszcie jako systemowo-strukturalną. Wszystkie te wymiary zgodne są z duchem przestrzennej metafory Freuda. W pierwszej wersji nieświadomość stanowi miejsce wypartych przedstawień i chaotycznych popędów, których proces porządkowania obrazuje rozwój życia seksualnego. W drugiej wersji nieświadomość określić

13 Zob. J.C. Milner, L'Oeuvre claire: Lacan, la science, la philosophie, Paris 1995 . 
można jako matrycę miejsca zawierającą w sobie obraz filogenezy odpowiedzialny za „przejście” z natury do kultury. W trzeciej wersji nieświadomość przestaje mieć charakter geometryczny - nie jest już miejscem, które dałoby się zlokalizować w aparacie psychicznym, nie jest nawet warunkiem możliwości takiej lokalizacji, ale stanowi system relacji mogący opisać m.in. „relacje geometryczne i topologiczne”. We wszystkich tych wersjach mamy do czynienia z odwróceniem odniesienia między głębią a powierzchnią, tym, co wewnętrzne, a tym, co zewnętrzne. Psychoanaliza nie traktuje nieświadomości jako siedziby symulakrów, głębinowych bytów, które rozbijają organizację powierzchni i przedstawienia (289), przeciwnie - we wszystkich wariantach stanowi ona warunek owej organizacji, sama możliwość przedstawienia jest jej „efektem”. Mityczna przestrzeń nie-sensu, szaleństwa i niemożliwości uzyskuje więc pozytywny status sfery narodzin fantazmatu. Nauka o wydarzeniach oznaczałaby taką teorię nieświadomości, która ukazuje jej „powierzchniowy” charakter w przestrzennej metaforyce wywodzącej się od Platona. Czyż Lacan nie usłyszał w tym obietnicy wzbogacenia własnej próby ulokowania psychoanalizy w porządku wiedzy?

Po trzecie, nauka o wydarzeniach, która nie traktuje swojego przedmiotu jako czegoś, czego sens „należy odnaleźć i wydobyć”, sytuuje się poza dualnym podziałem na nauki wyjaśniająco-przewidujące i opisująco-rozumiejące. Skonstruować musi więc na nowo sposób odniesienia do przedmiotu, przez co może nosić miano logiki sensu, być jak fenomenologia przednaukowa. Niemniej samą ową konstrukcję uznaje za arbitralną - w przeciwnym razie ograniczona byłaby przez sposób formalizacji, przez reguły logiczne: w terminologii Deleuze’a byłaby logiką znaczenia. Oczywiście nie oznacza to, że cechuje ją zupełna dowolność i brak poszanowania praw logiki - wszak mowa o nauce. Arbitralność polega tu raczej na niemożliwości wyczerpania wydarzenia, na niemożliwości usytuowania się poza nim, jest ono bowiem płaszczyzną immanencji - nauka $o$ wydarzeniu może mieć tylko charakter wydarzenia. W tym znaczeniu naukowość jest fantazmatem: „I jeśli to w tej cząstce, której urzeczywistnienie nie jest w stanie dopełnić, a przyczyna - wytworzyć, mieści się całość wydarzenia, to zarazem właśnie tutaj poddaje się ono również przeciwurzeczywistnieniu; właśnie tu tkwi nasza najwyższa wolność, dzięki której możemy owo wydarzenie rozwinąć i doprowadzić do końca, do punktu przeistoczenia, by wreszcie zapanować nad urzeczywistnieniami i przyczynami. Jako nauka czystych wydarzeń, psychoanaliza jest również sztuką przeciwurzeczywistnień, sublimacji i symbolizacji” (283). Nauka o wydarzeniu pozwala nam zapanować nad nieprzystawalnością sensu, jego nadmiarem albo brakiem, czymś, z czym 
żadna nauka poradzić sobie z definicji nie może. I gdy mowa tutaj o sztuce sublimacji i symbolizacji, możemy myśleć, że chodzi o sam proces psychoanalityczny, taki, który przechodził Człowiek-Szczur czy Człowiek-Wilk.

A jednak to nie psychoanalityczne przypadki opisane przez Freuda i jego następców interesują Deleuze’a. Logika sensu rozciąga się między nad-sensem Louisa Wolfsona, nonsensem Lewisa Carrolla a infra-sensem Antonina Artuada: wysokość, powierzchnia i głębia, pomiędzy neurozą a schizofrenią, między szaleństwem a „wielkim zdrowiem”. I tu raz jeszcze fantazmat psychoanalizy inauguruje swój proces, bowiem

psychoanaliza znajduje w szaleństwie par excellence - które psychiatrzy nazywają schizofrenią - bliską sobie, nieprzezwyciężalną udrękę: w szaleństwie tym dane są [...] wszelkie formy skończoności [...]. Psychoanaliza 'rozpoznaje się w jestestwie swoim', kiedy staje przed psychozami, do których mimo to (a raczej właśnie z tego powodu) nie ma dostępu: tak jakby psychoza w akcie okrutnej iluminacji wskazywała - nigdy za odległe, lecz zawsze za bliskie - miejsce, ku któremu analiza musi z wolna zmierzać ${ }^{14}$.

Dla Deleuze’a, podobnie jak dla Foucaulta, choć w innym kontekście, paradoksalne sąsiedztwo psychoanalizy i psychozy stanowi źródło żywotności i subwersywnej siły tej pierwszej. Fantazmat stanowi granicę bezpieczeństwa - jest tym konceptem, który w Logice sensu wprowadza w rezonans inne pojęcia psychoanalityczne i dlatego też jest wprowadzeniem do psychoanalizy. W odróżnieniu od innych kluczowych terminów Logiki sensu nigdzie indziej u Deleuze’a się już nie pojawia.

14 M. Foucault, Stowa i rzeczy: archeologia nauk humanistycznych, thum. T. Komendant, Gdańsk 2006, s. 337. 
Michał Gusin - pracownik Dolnośląskiej Szkoły Wyższej; tłumacz i historyk filozofii; jego polem zainteresowań jest filozofia współczesna z jej odniesieniami do różnych dziedzin wiedzy; obecnie przygotowuje pracę poświęconą związkom filozofii, anty-filozofii i psychoanalizy.

Dane adresowe:

Instytut Pedagogiki DSW

Ul. Strzegomska 55

53-611 Wrocław

e-mail: michalgusin@onet.eu

Cytowanie:

M. Gusin, Logika sensu: Deleuze’a wprowadzenie do psychoanalizy, „Praktyka Teoretyczna" nr 5/2012, http://www.praktykateoretyczna.pl/PT_ nr5_2012_Logika_sensu/04.Gusin.pdf (dostęp dzień miesiąc rok)

Author: Michał Gusin

Title: The Logic of Sense - Deleuze's introduction to psychoanalysis

Summary: Gilles Deleuze is well known as a philosopher who had a profound debat with psychoanalysis. This debate cannot be reduced to a critic of psychoanalysis alone because the universe in which Deleuze thinks and writes is heterogeneous and plural. In Logic of Sense, Freud's project, enriched by Melanie Klein or Jacques Lacan, is to point a metaphysical potentiality in the concepts of psychoanalysis. Psychoanalysis is called a "science of events" to create a net of connections between various series of the psychoanalytical insights. In my paper, I have tried to show how Deleuze determined the introduction to the debate with psychoanalysis. The key concept for his introduction is the notion of "phantasm" that is also rooted in the philosophical tradition.

Key words: psychoanalysis, phantasm, series, event 